Article

\title{
Species-Specific Discrimination of Insect Meals for Aquafeeds by Direct Comparison of Tandem Mass Spectra
}

\author{
Ikram Belghit ${ }^{1, *(\mathbb{D})}$, Erik-Jan Lock ${ }^{1}$, Olivier Fumière ${ }^{2} \mathbb{D}$, Marie-Caroline Lecrenier ${ }^{2}$, \\ Patricia Renard ${ }^{3}$ (D), Marc Dieu ${ }^{3,4}$, Marc H. G. Berntssen ${ }^{1}$, Magnus Palmblad ${ }^{5}$ and \\ Josef D. Rasinger ${ }^{1, *}$ \\ 1 Institute of Marine Research, P.O. Box 1870 Nordnes, 5817 Bergen, Norway; Erik-Jan.Lock@hi.no (E.-J.L.); \\ Marc.Berntssen@hi.no (M.H.G.B.) \\ 2 Centre Wallon de Recherches agronomiques (CRA-W), 5030 Gembloux, Belgium; \\ o.fumiere@cra.wallonie.be (O.F.); mc.lecrenier@cra.wallonie.be (M.-C.L.) \\ 3 University of Namur, rue de Bruxelles 61, B-5000 Namur, Belgium; patsy.renard@unamur.be (P.R.); \\ marc.dieu@unamur.be (M.D.) \\ 4 University of Namur, mass spectrometry facility (MaSUN), rue de Bruxelles 61, B-5000 Namur, Belgium \\ 5 Leids Universitair Medisch Centrum, 2316 Leiden, The Netherlands; N.M.Palmblad@lumc.nl \\ * Correspondence: Ikram.Belghit@hi.no (I.B.); Josef.Rasinger@hi.no (J.D.R.); \\ Tel.: +47-46-85-05-87 (I.B.); +47-90-36-28-98 (J.D.R.)
}

Received: 2 April 2019; Accepted: 5 May 2019; Published: 7 May 2019

check for updates

Simple Summary: Aquaculture is amongst the most efficient ways to produce animal protein for human consumption, and this sector is expected to continue to grow worldwide. Inclusion of novel protein sources, like insect meal, may help to mitigate the expected scarcities of feed resources and reduce environmental pressure. However, considered as processed animal protein (PAP), insect meal must comply with the respective legal constraints associated with PAP legislation to guarantee its safety for use as fish feed ingredients. Therefore, there is a need for the development of methods to identify and quantify the species origin of insect-based ingredients in aquafeed. In this study, we propose high-throughput tandem mass spectrometry for the identification and differentiation of 18 different insect meal samples from the species Hermetia illucens (8), Tenebrio molitor (5), Alphitobius diaperinus (3) and Acheta domesticus (2). Using high throughput proteomics tools in combination with direct spectral comparison, we were able to differentiate the insect meal samples according to the taxonomic classification of the insect species. Mass spectrometry-based proteomics is a powerful tool for the species-specific discrimination of insect meals for feed formulations.

Abstract: Insect protein has the potential to become a sustainable feed ingredient for the rapidly growing aquaculture industry. In the European Union, insect derived protein is placed under the same legislation as processed animal proteins (PAP). It is therefore of interest to develop methods for regulatory use, which unambiguously identify the species origin of insect-based ingredients. We performed (i) total protein quantification of insect samples using the traditional nitrogen-to-protein conversion factor of 6.25 and the sum of anhydrous amino acids, (ii) quantitative amino acid profiling and (iii) high-throughput tandem mass spectrometry to describe and differentiate 18 different commercial-grade insect meal samples derived from Hermetia illucens (8), Tenebrio molitor (5), Alphitobius diaperinus (3) and Acheta domesticus (2). In addition, we investigated and compared different protein extraction and digestion protocols for proteomic analysis. We found that irrespective of sample preparation, shotgun proteomics in combination with direct spectral comparison were able to differentiate insect meal according to their taxonomic classification. The insect specific spectral libraries created in the present work can in future be used to develop more sensitive targeted methods of insect PAP identification and quantification in commercial feed mixtures. 
Keywords: insect meal; shotgun proteomics; species differentiation; protein quantification

\section{Introduction}

Aquaculture is amongst the most efficient ways to produce animal protein for human consumption, and this sector is expected to continue to grow in the foreseeable future, putting more pressure on the world's existing protein sources [1]. Insects, which are part of the natural diet of many fish species, represent a novel sustainable protein resource that can be incorporated into future aquafeed production. The nutritional composition of insects has been widely reviewed with an emphasis on fat, essential minerals and vitamins [2,3]. They are rich in protein (varied depending on the species) and have a well-balanced essential amino acid profile, similar to the amino acids of fish meal (FM); the main conclusions being that many insect species can be optimal feedstuff for animals, including fish [4-8]. The most promising insect species for industrial feed production are black soldier fly (H. illucens) larvae, common housefly (Musca domestica) larvae, house cricket (A. domesticus) and yellow mealworm (T. molitor) $[9,10]$. These species have received increasing attention because they potentially valorize many types of organic side-streams (e.g., from food-producing factories) and produce high-quality protein that can be used in aquafeed [11].

According to a recent European Commission regulation (2017/893-24/05/2017), the use of insect meal (IM) from seven different insect species is allowed to be used in aquafeeds. As a consequence, a tremendous increase in investments in this sector has been observed. However, considered a processed animal protein (PAP) in the European Union (EU), insect feed ingredients must comply with the associated legal to guarantee their safe use in fish feed ingredients. Analytical approaches therefore must be developed which allow for an unambiguous detection and identification of white-listed insect species in insect-protein containing feed ingredients. To guarantee such a safe use of PAP, standard operating procedures (SOP) have been established for the control of aquafeeds by the European Union Reference Laboratory for Animal Protein (EURL-AP). These include the application of light microscopy to detect PAP when feed is not supposed to contain PAP and the use of an EURL-AP validated polymerase chain reaction (PCR) based method, which is used for ruminant DNA-detection when the feed is known to contain PAP or blood products, as indicated from the declaration or the labeling [12]. For insects, to date only a few studies investigated the applicability of qPCR for the detection of specific insects in compound feed. For example, Marien et al. [13], developed a qPCR assay for the detection of H. illucens; and Debode et al. [14], for the detection of T. molitor. Some investigators also looked at the applicability of light microscopy for different commercially available IMs from H. illucens, Gryllus assimilis, A. diaperinus, Bombyx mori and T. molitor $[15,16]$ or Fourier Transform Near Infrared spectroscopy approach (FTNIR) for the detection of T. molitor and A. Domesticus [17]. However, with the fast-growing number of insect species used for the production of insect meals, the detection, identification and differentiation of insect species by qPCR or microscopy remain a challenge. In addition, the current general paucity of information on insect species in molecular reference databases further hampers any efforts to develop targeted assays.

Proteomic-based methods using (tandem) mass spectrometry (MS) were, in a recent scientific opinion by the European Food Safety Authority (EFSA), identified as promising tools to complement current standard techniques of feed PAP detection [18]. Different laboratories specialized in feed and food safety have been developing promising MS based tools for the species-specific detection, differentiation and quantification of animal proteins [19-22]. Most of these methods are targeted approaches which are based on the detection of a known peptide or protein of which the sequence information is available $[23,24]$. However, similarly to qPCR-based methods, the lack of genetic information of many insect species currently impedes the development of targeted MS approaches for insect PAP. 
Therefore, alternative methods, which can be performed independently of genomic information, are needed to overcome these limitations. Recently, direct spectral library comparisons following an approach first described in Palmblad and Deelder [25] were used by Rasinger et al. [12] to differentiate PAP for aquafeeds according to their taxonomic classification. In the current study, a similar proteomics approach was used to differentiate between 18 commercial-grade insect protein meals derived from H. illucens (8), T. molitor (5), A. diaperinus (3) and A. domesticus (2). In addition, the insect meal samples were subjected to quantification of total protein and amino acid profiling.

\section{Materials and Methods}

\subsection{Sample Material}

In the present work, eighteen different commercial IM samples were selected based on their availability (IM produced by different companies): 8 samples from species of the Diptera order; black soldier fly larvae (BSF) (H. illucens), 8 samples from species of the Coeleoptera order, including the yellow mealworm (YW) (T. molitor) and the lesser mealworm (LW) (A. diaperinus) and 2 samples from the Orthoptera order; house cricket (HC) (A. domesticus) (Table 1).

Table 1. Insect protein samples included in the study, with the Latin name, order and the family belongings.

\begin{tabular}{cccc}
\hline Samples & Species & Latin Name & Order-Family \\
\hline BSF1-BSF8 & Black soldier fly & Hermetia illucens & Diptera- Stratiomyidae \\
YW9-YW13 & Yellow mealworm & Tenebrio molitor & Coleoptera-Tenebrionidae \\
LW14-LW16 & Lesser mealworm & Alphitobius diapernius & Coleoptera-Tenebrionidae \\
HC17-HC18 & House cricket & Acheta domesticus & Orthoptera- Gryllidae \\
\hline
\end{tabular}

$\mathrm{BSF}=$ black soldier fly; $\mathrm{YW}=$ yellow mealworm; $\mathrm{LW}=$ lesser mealworm; $\mathrm{HC}=$ house cricket.

\subsection{Amino Acid Analysis}

Amino acid analyses of IM samples were carried out by ultra-performance liquid chromatography (UPLC, Waters Acquity UPLC system) coupled with a UV detector following an accredited method by the Nordic Committee of Food Analysis (NMKL). The method is described in detail elsewhere [5,26,27]; in short, ground samples equivalent of $30-40 \mathrm{mg}$ of protein were hydrolyzed in $6 \mathrm{~N} \mathrm{HCl}$ at $110^{\circ} \mathrm{C}$ for $22 \mathrm{~h}$. Prior to hydrolysis, $3.125 \mathrm{mM}$ Norvaline (Sigma-Aldrich, St. Louis, MO, USA) was added as internal standard, and 0.1 M Dithiothreitol (DTT, Sigma-Aldrich) was added as an antioxidant agent to protect methionine from degradation during acid hydrolysis. For a further protective aid, a layer of $\mathrm{N} 2$ gas was put into the flasks for $30 \mathrm{~s}$, and then the flasks were capped immediately. During acid hydrolysis, tryptophan and cysteine were destroyed. After hydrolysis, the samples were cooled in cold water until room temperature was reached and centrifuged in a vacuum centrifuge to complete dryness. After centrifugation, the residues were diluted in deionized water and filtered through a syringe-driven filter. Prior to the instrumental analysis, a derivatization agent (AccQ.Tag TM, Waters, Milford, MA, USA) was added to each sample. Finally, amino acids were separated by UPLC (column: Aquity UPLC BEH C18 $1.7 \mu \mathrm{M}(2.1 \times 100 \mathrm{~mm})$, Waters, flowrate $\left.0.7 \mathrm{~mL} \mathrm{~min}^{-1}\right)$ and results integrated by Empower 3 (Waters). Amino acids were quantified using standards from Thermo Fisher Scientific (product number; 20088 Rockford, IL 61105, USA). Data was analyzed and visualized using Qlucore Omics Explorer version 3.3 (Qlucore AB, Lund, Sweden).

\subsection{Total Nitrogen}

Total nitrogen (TN) was analyzed according to the Dumas method [28]. Briefly, wet, ground IM samples using a CHNS elemental analyzer (Vario Macro Cube, Elementar Analysensysteme GmbH, Langenselbold, Germany), using helium as carrier gas. The instrument was calibrated with ethylene diamine tetra acetic acid (EDTA) (Leco Corporation, Saint Joseph, MI, USA). Sulfanilamide (Alfa 
Aesar GmbH \& Co, Karlsruhe, Germany) and a standard meat reference material (SMRD 2000, LGC Standards, Teddington, UK) was used as the control sample.

\section{Protein Content}

The protein content was quantified using; (i) the N-to protein factor of 6.25 (crude protein, CP) and (ii) as sum of amino acids residues [29] (true protein, TP). The amino acids residues were calculated as follows:

$$
\mathrm{E}_{\mathrm{i}}=\mathrm{AA}_{\mathrm{i}} \times\left(\frac{\mathrm{AA}_{\mathrm{i}}(\mathrm{MW})-\mathrm{H}_{2} \mathrm{O}(\mathrm{MW})}{\mathrm{AA}_{\mathrm{i}}(\mathrm{MW})}\right)
$$

where $=$ the proportion of the single amino acid ( $\mathrm{g}$ amino acid per $100 \mathrm{~g}$ of dry weight); $\mathrm{MW}=$ molecular weight of a single amino acids.

Calculation of N-Protein conversion factors $(k P)$ was determined for each IM sample as follows:

$$
\sum \frac{E_{i}}{T N}
$$

where $E_{i}$ represents the gram of the single amino acid residue per $100 \mathrm{~g}$ of dry weight and TN represents the gram of $\mathrm{N}$ per $100 \mathrm{~g}$ of dry weight.

\subsection{Proteomics Analysis}

\subsubsection{Extraction, Solubilization and Quantification of Proteins}

The proteins were extracted from the IM samples by using two different methods (protein extractions 1 and 2) in parallel in two different laboratories (laboratories A and B), respectively;

Protein Extraction 1:

Fifty (50) $\mathrm{mg}$ of IM samples was solubilized with 0.5 or $1 \mathrm{~mL}$ of lysis buffer (4\% SDS, $0.1 \mathrm{M}$ Tris- $\mathrm{HCl}, \mathrm{pH}$ 7.6). The samples were ground in tubes containing resin on ice using pestle (Sample Grinding Kit, GE Healthcare Life Science, 80648337, Piscataway, NJ, USA). Then, 1 M Dithiothreitol was added to the extraction solution, to obtain a final concentration of $0.1 \mathrm{M}$. Tubes were centrifuged for $10 \mathrm{~min}$ at maximum speed to remove resin and cellular debris. The supernatants were collected and heated at $95{ }^{\circ} \mathrm{C}$ for $5 \mathrm{~min}$ and then stored at $-20^{\circ} \mathrm{C}$ until further use.

Protein Extraction 2:

Two (2) $\mathrm{mL}$ of extraction buffer (200 mM Tris- $\mathrm{HCl}$, pH 9.2, 2M urea) was added to $200 \mathrm{mg}$ of IM samples. Samples were shaken for $30 \mathrm{~min}$ at room temperature in a Grant-bio rotating-shaker (Grant instruments Ltd, Camb, England) followed by sonication for $15 \mathrm{~min}$. Tubes were then centrifuged at $14,000 \mathrm{rpm}$ for $10 \mathrm{~min}$ at $4{ }^{\circ} \mathrm{C}$ and supernatants were collected. The obtained protein extracts samples were stored at $-20^{\circ} \mathrm{C}$ until further use.

At both laboratories, protein concentrations were determined by the Pierce ${ }^{\mathrm{TM}} 660 \mathrm{~nm}$ Protein Assay Reagent (ThermoFisher Scientific, Waltham, MA, USA) using BSA as protein standard (ThermoFisher Scientific).

\subsubsection{In-Solution Digestion of Proteins}

Insect protein extracts were digested using modified filter-aided sample preparation (FASP) method as described by Wiśniewski et al. [30] and Distler et al. [31]. At laboratory A, $50 \mu \mathrm{g}$ of the protein extracts were diluted with $200 \mu \mathrm{L}$ of $8 \mathrm{M}$ urea solution $(100 \mathrm{mM}$ Tris- $\mathrm{HCl}, \mathrm{pH} 8.5)$ and loaded into ultrafiltration spin column (Microcon 30, Millipore, Burlington, MA, USA). Proteins were then alkylated in $50 \mathrm{mM}$ of iodoacetamide $\left(\mathrm{C}_{2} \mathrm{H}_{4} \mathrm{INO}\right)$ for $20 \mathrm{~min}$ in darkness at room temperature. After that, the protein mixtures were washed with $200 \mu \mathrm{L}$ of $8 \mathrm{M}$ urea solution and $100 \mu \mathrm{L}$ of $50 \mathrm{mM}$ ammonium bicarbonate $\left(\mathrm{NH}_{4} \mathrm{HCO}_{3}\right)$ solution. Trypsin (1:50, enzyme to protein) was added and 
incubated with the protein mixture at $37^{\circ} \mathrm{C}$ for $16 \mathrm{~h}$. The filter unit was centrifuged and washed with $40 \mu \mathrm{L}$ of $50 \mathrm{mM}$ ammonium bicarbonate solution and $50 \mu \mathrm{L}$ of $0.5 \mathrm{M} \mathrm{NaCl}$. The eluents containing tryptic peptides were vacuum dried. At laboratory B, ultrafiltration spin columns (Microcon 30, Millipore) were washed with a $1 \%$ formic acid solution and $40 \mu \mathrm{g}$ of protein extracts were added to the membrane. After washing the filter with $8 \mathrm{M}$ urea in $100 \mathrm{mM}$ Tris- $\mathrm{HCl}(\mathrm{pH}$ 8.5), reduction and alkylation were conducted on the filter devices at $56{ }^{\circ} \mathrm{C}$ and room temperature, respectively. Excess of iodoacetamide was removed by an additional DTT incubation followed by a washing step with $50 \mathrm{mM}$ ammonium bicarbonate buffer. Then, $800 \mathrm{ng}$ of trypsin was added to the membrane and incubated overnight at $37^{\circ} \mathrm{C}$ for $16 \mathrm{~h}$. The next day, peptides were eluted by centrifugation at $11,000 \mathrm{~g}$ and a second elution was done with $50 \mathrm{mM}$ ammonium bicarbonate buffer. Samples were concentrated using a vacuum centrifuge.

Following trypsin digestions, at both laboratories, peptide concentrations were determined by adsorption at $280 \mathrm{~nm}$ wavelength using a Nanodrop 2000 (Thermo Scientific). Peptide samples (laboratories $\mathrm{A}$ and $\mathrm{B}$ ) were stored at $-20^{\circ} \mathrm{C}$ prior to mass spectrometry analysis.

\subsubsection{Mass Spectrometry}

All the proteins digest (extractions 1 and 2) were analyzed using an ESI-MS/MS maXis Impact UHR-TOF (Bruker, Billerica, MA, USA) coupled with an UltiMate 3000 HPLC system (Thermo Scientific) (chromatogram is presented in Figure S1). The digests were separated by reverse-phase liquid chromatography using a $1 \mathrm{~mm}$ I.D. $\times 150 \mathrm{~mm}$ reverse phase column (Acclaim PepMap 100 C18, Thermo Scientific). The flow rate was $40 \mu \mathrm{L} / \mathrm{min}$. Mobile phase A was $95 \%$ water, $5 \%$ acetonitrile, $0.1 \%$ formic acid. Mobile phase B was $20 \%$ water, $80 \%$ acetonitrile, $0.1 \%$ formic acid. The digest was injected and the organic content of the mobile phase was increased linearly from $4 \%$ B to $40 \%$ B in $60 \mathrm{~min}$ and from $40 \% \mathrm{~B}$ to $90 \% \mathrm{~B}$ in $10 \mathrm{~min}$, and then washed with $90 \%$ B for $10 \mathrm{~min}$ and with $4 \%$ B for $10 \mathrm{~min}$, for a total of $90 \mathrm{~min}$. The column effluent was directly connected to the MS. In survey scan, MS spectra were acquired for $0.5 \mathrm{sec}$ in the mass to charge $(\mathrm{m} / \mathrm{z})$ range between $50-2200$. The most intense peptides ions $2+$ to $4+$ were sequenced during a cycle time of $3 \mathrm{sec}$. The collision-induced dissociation (CID) energy was automatically set according to $\mathrm{m} / \mathrm{z}$ ratio and charge state of the precursor ion. The mass spectrometer and HPLC systems are controlled by Compass Hystar 3.2 (Bruker).

\subsection{Proteomics Bioinformatics and Data Mining}

Mass spectrometry data generated using the UHR-TOF (.baf files) were converted using compassXport (Bruker DataAnalysis 4.2) and saved as mgf and mzXML files. Standard bottom-up proteomics bioinformatics analysis was conducted using the proteoQC package (version 1.18.1) [32] in $\mathrm{R}$ (version 3.4.4) [33] running in RStudio (version 1.0.143) [34]. In short, mgf peak lists obtained from MS/MS spectra were subjected to the X!Tandem search engine [35] with the following parameter settings: (i) Trypsin was set as digestive enzyme and a maximum of two missed cleavages were allowed, (ii) MS1 and MS2 tolerances were set to $10.0 \mathrm{ppm}$ and 0.05 Da respectively, and (iii) carbamidomethylation of carbon and oxidation of methionine were set as fixed and variable modifications, respectively. The peak lists of BSF, YW, LW and HC were searched individually against their respective UniprotKB/Swiss-Prot (release 2019_01) reference proteomes (Table 2). Protein identifications were inferred from peptide identifications; each identified protein had at least one associated unique peptide sequence identified at q-value equal or less than 0.01 (equivalent to a 1\% FDR). The Occam's razor approach [36] was applied to deal with degenerate peptides by finding a minimum subset of proteins that covered all of the identified peptides. Insect specific proteins and peptides detected across both laboratories and analyses are reported (Online resource). To compare LC-MS/MS datasets directly, independently of sequence databases, DISMS2 was used, a spectral library comparison pipeline frequently used to calculate proteome-wide distances between samples without suitable peptide/protein reference databases [37]. Venn diagrams comparing the numbers of peptides and proteins are presented with an interactive tool for comparing lists with Venn's diagrams [38]. 
Table 2. Taxon identifier and number of proteins of H. illucens, T. molitor, A. diaperinus and A. domesticus.

\begin{tabular}{ccc}
\hline Species & Taxon Identifier & Number of Proteins (UNIPROT) \\
\hline H. illucens & 343,691 & $71(1)$ \\
T. molitor & 7067 & $532(26)$ \\
A. diaperinus & 27,448 & $28(0)$ \\
A. domesticus & 6997 & $131(4)$ \\
\hline
\end{tabular}

Number of predicted and (reviewed) proteins of H. illucens, T. molitor, A. diaperinus and A. domesticus listed in the UniprotKB/Swiss-Prot reference proteome database.

\section{Results and Discussion}

\subsection{Quantification of Total Protein and Amino Acid Profiling}

Insect meal has been highlighted as a suitable replacement of FM and plant-based diets, such as soy protein, in fish diets $[2,3,5,8]$. However, when novel proteic feed components are introduced, the amino acid (AA) composition should be well balanced in order to meet the requirements of fish species. The AA profile of IM samples studied in the current study were comparable to those given in previous reports for BSF, YW, LW and HC [39,40] (Table 3). Moreover, the IM investigated contained all the essential AA and in quantities that are similar or even higher than FM and soy protein, except for lysine and methionine (Table 3). In aquafeed, these two AAs are the main limiting essential AAs and are generally supplemented in the plant-based diets in order to fulfil the requirement of carnivorous fish species [41,42]. Among the four insect species analyzed in the current study, only HC and LW meals were found to contain taurine; in BSF and YW meals taurine levels were not detected (Table 3). It was also found that the amount of taurine was much higher in IM samples derived from HC than LW species $(0.8-1 \%$ and $0.2-0.3 \%$ of crude protein, respectively) (Table 3). Similar results have been reported by Finke [43], where HC contained substantial level of taurine when compared to other insect species (zophobas morio, T. molitor, galleria mellonella and lumbricus terresstris). In the present study, the amount of taurine detected in HC meals ( $5 \mathrm{~g} / \mathrm{kg}$ wet basis) was higher even than the levels reported by Finke $(0.18 \mathrm{mg} / \mathrm{g}$ wet basis) (Table S1) [43,44]. Similarly to a typical herring FM, which has taurine level between $0.5-2 \%$ of crude protein, the HC meal might therefore be a suitable source of taurine in future fish feed formulations [45].

Table 3. Total amino acid composition (\% of crude protein) of the 18 insect meal samples.

\begin{tabular}{|c|c|c|c|c|c|c|c|c|c|c|c|c|c|c|c|c|c|}
\hline Species & Ala & Arg & Asp & Glu & Gly & His & Ile & Leu & Lys & Met & Phe & Pro & Ser & Tau & Thr & Tyr & Val \\
\hline BSF 1 & 9.5 & 6.2 & 12.4 & 16.0 & 6.7 & 3.8 & 5.2 & 8.8 & 6.9 & 2.0 & 5.2 & 8.8 & 6.0 & $<\mathrm{LoD}$ & 5.2 & 8.1 & 7.4 \\
\hline BSF 2 & 7.7 & 6.8 & 12.3 & 14.2 & 7.1 & 4.2 & 5.2 & 8.7 & 7.7 & 2.4 & 6.5 & 7.7 & 5.5 & $<\mathrm{LoD}$ & 5.2 & 9.4 & 7.1 \\
\hline BSF 3 & 8.1 & 5.6 & 12.6 & 15.2 & 6.7 & 3.3 & 5.2 & 8.5 & 8.1 & 2.1 & 5.6 & 7.4 & 5.6 & $<\mathrm{LoD}$ & 5.2 & 8.1 & 7.4 \\
\hline BSF 4 & 8.2 & 6.7 & 12.4 & 15.5 & 6.7 & 3.9 & 5.5 & 8.8 & 8.8 & 2.1 & 5.2 & 7.0 & 5.5 & $<\mathrm{LoD}$ & 5.2 & 7.9 & 7.0 \\
\hline BSF 5 & 8.1 & 6.1 & 13.9 & 13.9 & 6.4 & 3.6 & 5.6 & 9.4 & 8.1 & 2.6 & 6.4 & 6.9 & 5.3 & $<\mathrm{LoD}$ & 5.3 & 8.6 & 7.2 \\
\hline BSF 6 & 13.1 & 4.5 & 8.6 & 10.0 & 8.6 & 2.8 & 5.5 & 10.3 & 5.2 & 1.4 & 4.1 & 10.7 & 6.6 & $<\mathrm{LoD}$ & 4.5 & 10.7 & 9.3 \\
\hline BSF 7 & 7.1 & 6.9 & 13.6 & 13.8 & 6.0 & 3.8 & 5.5 & 9.3 & 9.0 & 2.7 & 6.4 & 6.2 & 5.2 & $<\mathrm{LoD}$ & 5.5 & 7.9 & 6.7 \\
\hline BSF 8 & 7.3 & 6.4 & 13.2 & 12.7 & 6.4 & 3.4 & 5.5 & 9.5 & 9.1 & 2.7 & 6.4 & 7.0 & 5.5 & $<\mathrm{LoD}$ & 5.2 & 8.9 & 7.3 \\
\hline YW 9 & 9.0 & 6.9 & 10.8 & 14.7 & 6.7 & 3.7 & 5.5 & 9.6 & 7.5 & 1.7 & 5.1 & 8.2 & 5.9 & $<\mathrm{LoD}$ & 5.1 & 9.0 & 7.6 \\
\hline YW 10 & 9.2 & 6.7 & 10.8 & 14.6 & 6.7 & 3.8 & 5.4 & 9.2 & 7.4 & 1.7 & 4.6 & 8.7 & 5.9 & $<\mathrm{LoD}$ & 5.1 & 9.0 & 7.2 \\
\hline YW 11 & 9.2 & 6.8 & 10.8 & 14.5 & 6.6 & 3.7 & 5.3 & 9.2 & 7.4 & 1.7 & 4.7 & 8.7 & 6.1 & $<\mathrm{LoD}$ & 5.3 & 9.5 & 7.4 \\
\hline YW 12 & 9.0 & 6.7 & 11.0 & 15.0 & 6.9 & 3.3 & 5.6 & 10.0 & 6.7 & 1.8 & 5.2 & 8.1 & 6.0 & $<\mathrm{LoD}$ & 5.4 & 8.8 & 7.5 \\
\hline YW 13 & 9.5 & 7.6 & 10.8 & 15.1 & 6.8 & 3.8 & 5.4 & 9.7 & 8.1 & 1.7 & 4.6 & 8.6 & 6.2 & $<\mathrm{LoD}$ & 5.4 & 7.6 & 7.6 \\
\hline LW 14 & 8.1 & 6.7 & 11.4 & 16.0 & 5.6 & 4.0 & 5.1 & 8.4 & 8.6 & 1.8 & 5.6 & 7.2 & 5.3 & 0.3 & 5.1 & 9.3 & 6.5 \\
\hline LW 15 & 8.1 & 6.7 & 11.6 & 15.8 & 5.6 & 4.0 & 5.1 & 8.4 & 8.4 & 1.8 & 5.8 & 7.7 & 5.3 & 0.2 & 5.1 & 9.8 & 6.7 \\
\hline LW 16 & 8.1 & 6.7 & 11.9 & 15.8 & 5.6 & 4.0 & 5.3 & 8.6 & 8.8 & 1.8 & 5.8 & 7.9 & 5.3 & 0.2 & 5.1 & 9.8 & 6.7 \\
\hline HC 17 & 11.1 & 8.7 & 11.7 & 14.3 & 7.0 & 3.0 & 5.0 & 9.3 & 7.2 & 2.1 & 4.6 & 7.6 & 6.5 & 1.0 & 4.8 & 6.5 & 6.7 \\
\hline HC 18 & 10.7 & 8.3 & 10.5 & 14.9 & 6.8 & 2.9 & 4.9 & 9.3 & 7.8 & 2.1 & 4.6 & 7.3 & 5.4 & 0.8 & 5.1 & 8.5 & 7.1 \\
\hline FM * & 6.1 & 5.2 & 9.3 & 13.1 & 6.6 & 2.1 & 5.1 & 6.5 & 10.1 & 3.1 & 3.7 & 4.2 & 4.4 & 1.0 & 3.5 & 2.9 & 4.5 \\
\hline SP * & 3.7 & 5.1 & 11.5 & 20.7 & 3.7 & 1.3 & 4.0 & 6.1 & 3.7 & 1.4 & 3.4 & 5.1 & 5.3 & - & 3.7 & 3.1 & 4.5 \\
\hline
\end{tabular}

$\mathrm{BSF}$ = black soldier fly; YW = yellow mealworm; $\mathrm{LW}=$ lesser mealworm; $\mathrm{HC}=$ house cricket; $\mathrm{FM}=$ fish meal; $\mathrm{SP}=$ soy protein; $<$ LoD $=<$ minor than Limit of Detection; $[46,47]$. 
The AA composition of the eighteen IM samples studied varied between the species (Table 3). A principal component analysis (PCA) was applied to the AAs data and resulted in a clear distinction between the amino acids profile of HC, BSF, LW and YW meals, respectively (Figure 1a). Euclidean distance clustering confirmed these patterns, as demonstrated by the heat maps in Figure 1b. In addition, a clustering of amino acid profiles was observed which reflected the taxonomic classification of the insect species; Diptera, Coleoptera and Orthoptera (Figure 1b). IM derived from BSF species, however, was separated into two different groups based on the AA profile (Figure 1b). This observation might be related to the different processing steps the IM was subjected to, which differed between the commercial companies supplying the samples. For example, some samples were labeled as defatted; a process which increases the crude protein content and consequently the AAs composition of IM from different insect species $[40,48]$. However, since no further information was provided about the processing steps performed by the different IM producers, its effects on AA composition remains to be investigated.
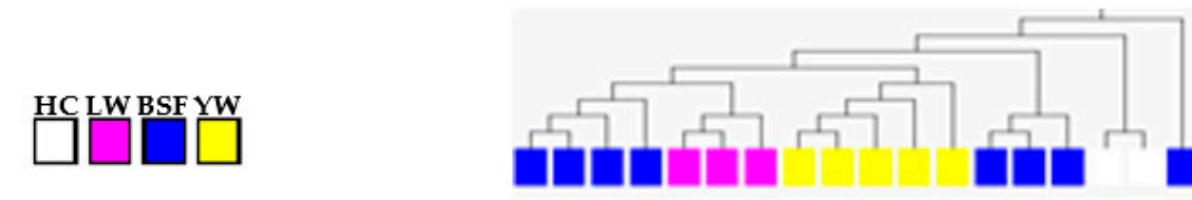

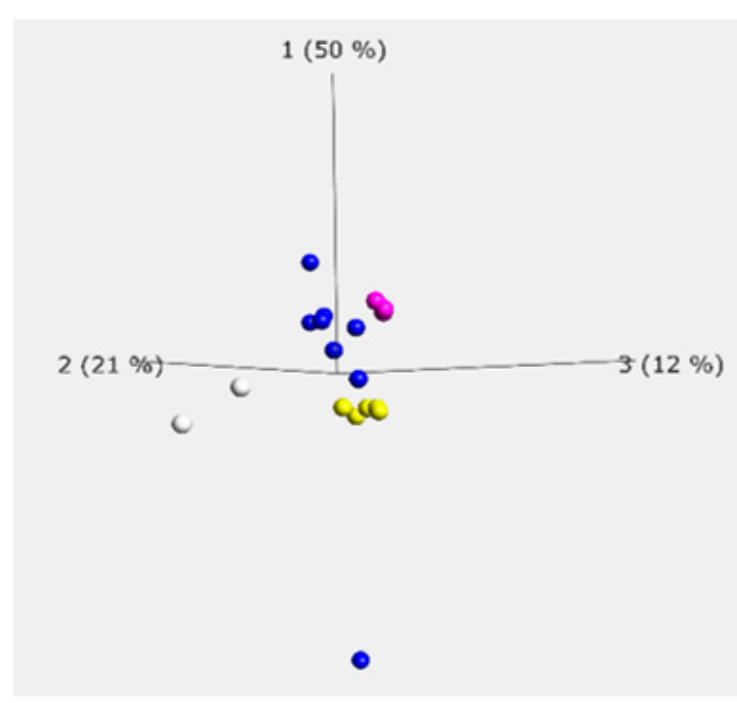

(a)

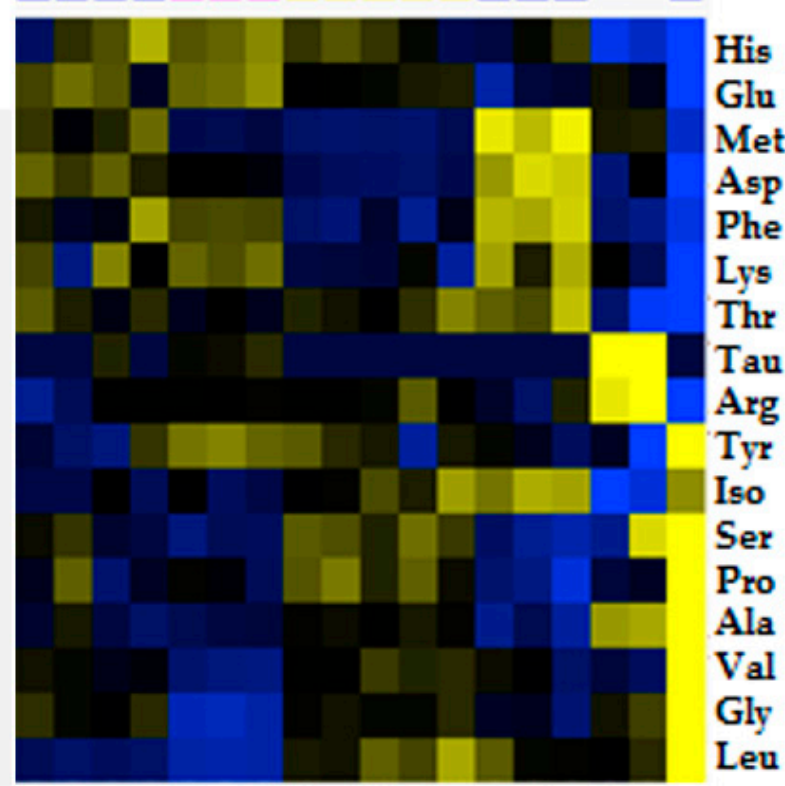

(b)

Figure 1. Principal analysis (PCA) and hierarchical clustering analysis of the amino acids content from 18 IM samples: (a) The plot shows the three components, PC1 (50\%), PC2 (21\%) and PC3 (12\%). The white, pink, blue and yellow dots represent house cricket (HC), lesser mealworm (LW), black solider fly (BSF) and yellow mealworm (YW), respectively; (b) Semi-quantitative visual heat map representation of amino acids content in the 18 IM samples. The white, pink, blue and yellow square represent house cricket (HC), lesser mealworm (LW), black solider fly (BSF) and yellow mealworm (YW), respectively. Each line in the heat map represents the content of amino acids. The deeper the yellow color, the higher is the amino acid content in the respective sample; similarly, the deeper the blue color, the lower is the amino acids content in the respective sample.

The protein content of the eighteen IM samples is shown as both crude protein (based on total nitrogen, calculated by using nitrogen-to-protein conversion factor of 6.25) and true protein (sum of anhydrous AAs) in Table 4. Crude protein values of the IM samples were found to be much higher than the true protein amounts with an overestimation of the protein content ranging between $20-28 \%$ 
(Table 4). This overestimation by using the standard 6.25 N-to-protein factor is due to the presence of the non-protein nitrogen in insect species. Janssen et al. [39], calculated the specific N-protein conversion factor for BSF, YW and LW species and found a $k P$ value of 4.76. Similarly, in the current study, the $k P$ values calculated for BSF, YW, LW and HC meals varied between 4.21-5.01, 4.64-4.86, 4.83-5.0 and 4.53-4.80, respectively (Table 4). In other words, the nitrogen-to-protein conversion factors calculated in the present study are in line with data reported in the literature [27,39] and provide for a more correct estimate of the IM protein content which is a vital determinant when insects are to replace current protein sources in aquafeed.

Table 4. Crude protein (CP, expressed as percentage of wet weight) and true protein (TP) content of 18 insect meal samples, and difference between $\mathrm{CP}$ and TP $(\Delta \%)$ and N-Prot conversion factors.

\begin{tabular}{ccccc}
\hline Abbr & CP & TP & $\boldsymbol{\Delta} \%$ & N-Prot Factor \\
\hline BSF1 & 72 & 42 & 28 & 4.51 \\
BSF2 & 76 & 31 & 24 & 4.74 \\
BSF3 & 73 & 27 & 27 & 4.59 \\
BSF4 & 73 & 33 & 27 & 4.55 \\
BSF5 & 78 & 36 & 22 & 4.85 \\
BSF6 & 67 & 29 & 33 & 4.21 \\
BSF7 & 78 & 42 & 21 & 4.91 \\
BSF8 & 80 & 44 & 20 & 5.01 \\
YW9 & 76 & 51 & 24 & 4.73 \\
YW10 & 75 & 39 & 25 & 4.67 \\
YW11 & 77 & 38 & 23 & 4.81 \\
YW12 & 78 & 52 & 22 & 4.86 \\
YW13 & 74 & 37 & 26 & 4.64 \\
LW14 & 78 & 43 & 22 & 4.89 \\
LW15 & 81 & 43 & 19 & 5.05 \\
LW16 & 80 & 43 & 20 & 4.98 \\
HC 17 & 73 & 46 & 27 & 4.53 \\
HC18 & 77 & 41 & 23 & 4.80 \\
\hline
\end{tabular}

Protein content of the insect meal samples is presented both as crude protein (calculated as the total nitrogen, using the nitrogen-to-protein factor of 6.25 and true protein (calculated as sum of amino acids residues) (for more details, see material and methods section); $\mathrm{TP}=$ true protein; $\mathrm{CP}=$ crude protein; $\Delta \%=$ difference between $\mathrm{CP}$ and $\mathrm{TP}$ in $\%$; $\mathrm{BSF}=$ black soldier fly; $\mathrm{YW}=$ yellow mealworm; $\mathrm{LW}=$ lesser mealworm; $\mathrm{HC}=$ house cricket.

\subsection{Proteomics Analysis of Insect Meal Samples}

Protein extraction and solubilization are key steps for protein identification in bottom-up proteomics [49]. The protein concentration and yield obtained from the two different methods used to extract protein from IM samples are presented in Table S2. The protein extraction efficiencies varied largely between insect samples and also between the two extraction methods. In both methods tested, the protein recoveries were higher in the samples extracted from LW (20-58\% and 5-13\%, extraction 1 and 2, respectively) than that from BSF, YW and HC species (Table S2). The relative protein yield obtained by using a 4\% SDS and $0.1 \mathrm{M}$ Tris- $\mathrm{HCl}, \mathrm{pH} 7.6$ based buffer (extraction 1 ) in general was higher for all investigated IMs samples than the one obtained using a $200 \mathrm{mM}$ Tris- $\mathrm{HCl}, \mathrm{pH} 9.2,2$ M urea-based buffer (extraction 2; Table S2). These differences in protein concentration between the two extraction methods might indicate a possible effect of the different steps and reagents used for protein extraction. In extraction 1, samples were ground to fine powder. This increases the surface to volume ratio and facilitates the permeation of the sample with homogenization buffer achieving a higher extraction yield [49]. In addition, in extraction 1, SDS was used, which is known as an anionic detergent with superior solubilization power. These factors might in part explain the higher yield obtained for extraction 1 . However, the large degree of variability between both samples and methods used calls for additional experiments to optimize and standardize extractions procedure since protein isolation is the first critical step for proteomic studies [50]. 
In earlier work on PAP we demonstrated that data mining techniques can successfully be applied to bottom-up shotgun mass spectrometry data to obtain robust and reliable species-specific peptide markers [12]. However, this approach requires common proteins to be identified across all species of interest [23]. In the present work, the mass spectra obtained were analyzed using proteoQC [51] (mass spectra of all samples are available online), a total of 1360 peptides and 173 insect specific proteins were identified (see Tables S3 and S4 and MassIVE dataset [52]). Only 269 peptides and 86 proteins were detected consistently across the two laboratories (see Figure 2, Tables S5 and S6 and MassIVE dataset [52]). As can be seen in Table 5, the bulk of these proteins were identified in samples derived from YW; only a handful of proteins were identified in samples derived from BSF and HC and no proteins were identified in samples derived from LW (Table 5). As was observed previously, the rate of PAP protein identification is mainly related to the size of the UniprotKB/Swiss-Prot databases [51].

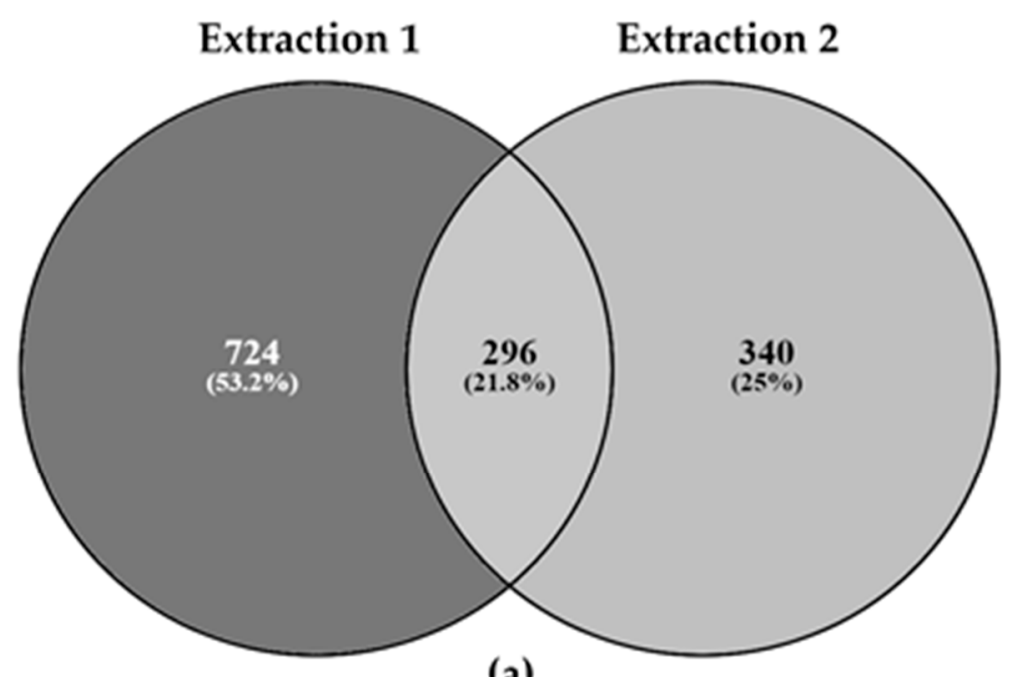

(a)



(b)

Figure 2. Venn diagrams comparing the numbers of peptides (a) and proteins (b) detected in 18 IM samples using a bottom-up proteomics. Extraction 1 and 2 refer to the two different extraction methods applied in Laboratory A and B. The intersection of the two circles shows the number of commonly detected peptides (a) and proteins (b). 
Table 5. Total numbers of spectra and successfully identified insect specific proteins and peptides in 18 insect meal samples, performed independently at two different laboratories (A and B).

\begin{tabular}{ccccccccc}
\hline Species & \multicolumn{3}{c}{ Extraction 1 } & \multicolumn{5}{c}{ Extraction 2 } \\
\hline & tSpectra & iSpectra & Peptides & Proteins & tSpectra & iSpectra & Peptides & Proteins \\
\hline BSF1 & 14,656 & 4 & 4 & 4 & 16,235 & 4 & 4 & 1 \\
BSF2 & 14,620 & 35 & 23 & 10 & 15,712 & 13 & 8 & 2 \\
BSF3 & 14,182 & 6 & 5 & 4 & 15,724 & 12 & 11 & 1 \\
BSF4 & 14,514 & 21 & 15 & 9 & 16,616 & 5 & 4 & 1 \\
BSF5 & 11,671 & 25 & 14 & 10 & 15,992 & 5 & 4 & 2 \\
BSF6 & 11,856 & 73 & 23 & 7 & 11,909 & 4 & 1 & 1 \\
BSF7 & 13,527 & 19 & 9 & 7 & 14,608 & 7 & 5 & 4 \\
BSF8 & 14,499 & 18 & 14 & 8 & 16,458 & 7 & 7 & 3 \\
YW9 & 17,416 & 1 & 1 & 1 & 15,469 & 1483 & 365 & 54 \\
YW10 & 13,671 & 1422 & 406 & 84 & 14,551 & 1256 & 304 & 62 \\
YW11 & 14,343 & 1987 & 548 & 103 & 11,778 & 4 & 2 & 2 \\
YW12 & 13,920 & 2138 & 431 & 69 & 12,986 & 758 & 140 & 33 \\
YW13 & 15,042 & 1627 & 524 & 92 & 16,837 & 958 & 414 & 72 \\
LW14 & 13,955 & 0 & 0 & 0 & 15,074 & 0 & 0 & 0 \\
LW15 & 12,654 & 0 & 0 & 0 & 14,267 & 0 & 0 & 0 \\
LW16 & 13,341 & 0 & 0 & 0 & 14,392 & 0 & 0 & 0 \\
HC17 & 13,732 & 39 & 16 & 5 & 15,327 & 132 & 22 & 3 \\
HC18 & 13,131 & 33 & 11 & 6 & 14,520 & 83 & 14 & 2 \\
\hline
\end{tabular}

$\mathrm{tSpectra}=$ total spectra determined; iSpectra = spectra identified; BSF = black soldier fly; $\mathrm{YW}=$ yellow mealworm; $\mathrm{LW}=$ lesser mealworm; $\mathrm{HC}=$ house cricket.

Despite the importance of insects for agricultural ecosystems, many insect species lack up-to-date genomic data [53], which is a challenge for the development and application of insect specific molecular tools. When there is a paucity of genomics information, direct comparisons of mass spectra can be performed [37]. We recently demonstrated that using compareMS2, an approach for the direct pairwise comparison of tandem mass spectra [25], allowed for the species and tissue specific differentiation of PAP of bovine, ovine, porcine and avian origin [12]. Contrary to the identification of peptides and proteins using database dependent search algorithms, tools like compareMS2 and the recently published DISMS2 [37] make use of the bulk of high quality tandem mass spectra rather than relying on selected few. As can be seen in Table 5, when applying a peptide mass fingerprinting approach, only a fraction of the detected spectra (tSpectra) was used in the identification and differentiation of IM peptides (iSpectra). In the current study, we present two representative dendrograms of DISMS2, a pipeline used to calculate distance matrices created from tandem mass spectra (Figure 3). All mass spectra of samples from extraction 1 were used and successfully arranged the 18 samples according to the insect species they originated from (Figure 3). In addition, in accordance with to the amino acid profile data (Figure 1b), also the spectral library clustering reflected the taxonomic classification of the insect order (Diptera, Coleoptera and Orthoptera). Phylogenetic analysis of data obtained from extraction 2, also correctly arranged the 18 samples according to the taxonomic classification; however, with two exceptions (BSF6 and YW13). This difference in clustering observed could be due to the different extraction methods used and highlights once again that an optimization and standardization of the protein extraction procedures is critical for proteomics analyses [50]. In addition to sample preparation the application of filter settings of the DISMS2 algorithms can be optimized to yield best results in specific situations [37]. Therefore, optimization of both sample preparation and algorithm settings should be investigated further to allow for the creation of high-quality PAP spectral library reference collections suitable for differentiation of insect PAP in feed mixes. Possibly, such library collections could in the future also be used for quantification of insect proteins in feed mixes as recently demonstrated for raw and processed fish and meat samples [20,54,55]. Additionally, spectral libraries can be mined for suitable signature spectra, which can be used for the generation of specific targeted 
mass spectrometry assays for absolute quantification of PAP in feed mixtures at legal limits of below $0.1 \%(\mathrm{w} / \mathrm{w})$.


Figure 3. Species specific insect meal samples differentiation. Direct comparison of spectra obtained by tandem mass spectrometry usingDISMS2. With two exceptions (BSF6 and YW13 in Laboratory B) insect meal samples cluster according to the taxonomic classification of the insect species.

\section{Conclusions}

In conclusion, our results confirmed the suitability of insect meals as a source of proteins for future fish feed formulations. A nitrogen-to-protein conversion factor of $\sim 4.21-5.0$ may be more suitable than the usual factor of 6.25 , when quantifying total protein content of insect meals derived from BSF, YM, LW and HC. The different sample preparation approaches employed in the present work strongly affected total protein yield and identification rates in bottom-up proteomics. To a lesser extent also the direct spectral comparisons were affected by the different protein extraction and digestion 
procedures employed; yet the DISMS2 algorithm was able to successfully differentiate insect meals according to their taxonomic groups. It is therefore of interest to further explore the use of database agnostic approaches for regulatory uses which aim for the identification and differentiation of the species origin of insect-based feed ingredients. Future work will focus on the standardization of sample preparation procedures and the creation of an extensive high quality and freely available insect PAP spectral library reference collection, which can be used for species identification by spectral library matching, as exemplified in [56] and for the development of highly sensitive targeted mass spectrometry assays, respectively.

Supplementary Materials: The following are available online at http://www.mdpi.com/2076-2615/9/5/222/s1, Figure S1: A representative LC chromatogram of IM sample, Table S1: Amino acid composition of 18 IM samples in $\mathrm{mg} / \mathrm{g}$ wet weight, Table S2: Protein (Pr) and protein yield (Py) quantified using two different protein extraction protocols; Table S3: Insect specific peptides identified using two different protein extraction protocols in laboratories A and B, Table S4: Insect specific proteins identified using two different protein extraction protocols in laboratories A and B; Table S5: Insect specific peptides commonly identified using two different protein extraction protocols in laboratories A and B, Table S6: Insect specific proteins commonly identified using two different protein extraction protocols in laboratories $\mathrm{A}$ and $\mathrm{B}$.

Author Contributions: Conceptualization, E.-J.L., J.D.R. and M.H.G.B.; Data curation, M.D.; Formal analysis, I.B., M.P. and J.D.R.; Investigation, I.B., E.-J.L, O.F., M.-C.L. and J.D.R.; Methodology, I.B., M.-C.L., P.R., M.D., M.P. and J.D.R.; Project administration, I.B., E.-J.L. and M.H.G.B.; Software, M.D., M.P. and J.D.R.; Writing-original draft, I.B. and J.D.R.; Writing -review \&original draft, O.F., M.-C.L., P.R., M.D. and M.H.G.B.

Funding: This study was supported by the Norwegian Research Council project ENTOFÔR, grant number 268344.

Acknowledgments: Thanks to the different companies for providing insect meal samples. The authors wish to acknowledge the contribution of Eva Mykkeltvedt for assisting during lab analysis.

Conflicts of Interest: No potential conflicts of interest were reported by the author(s).

\section{References}

1. Froehlich, H.E.; Runge, C.A.; Gentry, R.R.; Gaines, S.D.; Halpern, B.S. Comparative terrestrial feed and land use of an aquaculture-dominant world. PNAS 2018, 115, 5295-5300. [CrossRef] [PubMed]

2. Tran, G.; Heuzé, V.; Makkar, H.P.S. Insects in fish diets. Anim. Front. 2015, 5, 37-44.

3. Nogales-Mérida, S.; Gobbi, P.; Józefiak, D.; Mazurkiewicz, J.; Dudek, K.; Rawski, M.; Kierończyk, B.; Józefiak, A. Insect meals in fish nutrition. Rev. Aquacult. 2018, 0. [CrossRef]

4. Lock, E.R.; Arsiwalla, T.; Waagbø, R. Insect larvae meal as an alternative source of nutrients in the diet of Atlantic salmon (Salmo salar) postsmolt. Aquacult. Nutr. 2016, 22, 1202-1213. [CrossRef]

5. Belghit, I.; Liland, N.S.; Waagbø, R.; Biancarosa, I.; Pelusio, N.; Li, Y.; Krogdahl, Å.; Lock, E.-J. Potential of insect-based diets for Atlantic salmon (Salmo salar). Aquaculture 2018, 491, 72-81. [CrossRef]

6. Magalhães, R.; Sánchez-López, A.; Leal, R.S.; Martínez-Llorens, S.; Oliva-Teles, A.; Peres, H. Black soldier fly (Hermetia illucens) pre-pupae meal as a fish meal replacement in diets for European seabass (Dicentrarchus labrax). Aquaculture 2017, 476, 79-85. [CrossRef]

7. Belghit, I.; Waagbø, R.; Lock, E.-J.; Liland, N.S. Insect-based diets high in lauric acid reduce liver lipids in freshwater Atlantic salmon. Aquacult. Nutr. 2019, 25, 343-357. [CrossRef]

8. Belghit, I.; Liland, N.S.; Gjesdal, P.; Biancarosa, I.; Menchetti, E.; Li, Y.; Waagbø, R.; Krogdahl, Å.; Lock, E.-J. Black soldier fly larvae meal can replace fish meal in diets of sea-water phase Atlantic salmon (Salmo salar). Aquaculture 2019, 503, 609-619. [CrossRef]

9. Veldkamp, T.; Duinkerken, G.; Huis, A.; Lakemond, C.M.M.; Ottevanger, E.; Bosch, G.; Boekel, T. Insects as a Sustainable Feed Ingredient in Pig and Poultry Diets: A Feasibility Study = Insecten Als Duurzame Diervoedergrondstof in Varkens- en Pluimveevoeders: Een Haalbaarheidsstudie; Wageningen UR Livestock Research: Lelystad, The Netherlands, 2012; Rapport 638.

10. Van Huis, A. Potential of Insects as Food and Feed in Assuring Food Security. Annu. Rev. Entomol. 2013, 58, 563-583. [CrossRef] [PubMed]

11. Nguyen, T.T.X.; Tomberlin, J.K.; Vanlaerhoven, S. Ability of Black Soldier Fly (Diptera: Stratiomyidae) Larvae to Recycle Food Waste. Environ. Entomol. 2015, 44, 406-410. [CrossRef] 
12. Rasinger, J.D.; Marbaix, H.; Dieu, M.; Fumière, O.; Mauro, S.; Palmblad, M.; Raes, M.; Berntssen, M.H.G. Species and tissues specific differentiation of processed animal proteins in aquafeeds using proteomics tools. J. Proteomics 2016, 147, 125-131. [CrossRef]

13. Marien, A.; Debode, F.; Aerts, C.; Ancion, C.; Francis, F.; Berben, G. Detection of Hermetia illucens by real-time PCR. J. Insects Food Feed 2018, 4, 115-122. [CrossRef]

14. Debode, F.; Marien, A.; Gérard, A.; Francis, F.; Fumière, O.; Berben, G. Development of real-time PCR tests for the detection of Tenebrio molitor in food and feed. Food Addit. Contam. Part A 2017, 34, 1421-1426. [CrossRef] [PubMed]

15. Ottoboni, M.; Tretola, M.; Cheli, F.; Marchis, D.; Veys, P.; Baeten, V.; Pinotti, L. Light microscopy with differential staining techniques for the characterisation and discrimination of insects versus marine arthropods processed animal proteins. Food Addit. Contam. Part A 2017, 34, 1377-1383. [CrossRef] [PubMed]

16. Veys, P.; Baeten, V. Protocol for the isolation of processed animal proteins from insects in feed and their identification by microscopy. Food Control 2018, 92, 496-504. [CrossRef]

17. Mandrile, L.; Fusaro, I.; Amato, G.; Marchis, D.; Martra, G.; Rossi, A.M. Detection of insect's meal in compound feed by Near Infrared spectral imaging. Food Chem. 2018, 267, 240-245. [CrossRef] [PubMed]

18. Ricci, A.; Allende, A.; Bolton, D.; Chemaly, M.; Davies, R.; Fernández Escámez, P.S.; Gironés, R.; Herman, L.; Koutsoumanis, K.; Lindqvist, R.; et al. Updated quantitative risk assessment (QRA) of the BSE risk posed by processed animal protein (PAP). EFSA J. 2018, 16, 05314.

19. Lam, H.; Deutsch, E.W.; Eddes, J.S.; Eng, J.K.; Stein, S.E.; Aebersold, R. Building consensus spectral libraries for peptide identification in proteomics. Nat. Met. 2008, 5, 873. [CrossRef]

20. Ohana, D.; Dalebout, H.; Marissen, R.J.; Wulff, T.; Bergquist, J.; Deelder, A.M.; Palmblad, M. Identification of meat products by shotgun spectral matching. Food Chem. 2016, 203, 28-34. [CrossRef]

21. Steinhilber, A.E.; Schmidt, F.F.; Naboulsi, W.; Planatscher, H.; Niedzwiecka, A.; Zagon, J.; Braeuning, A.; Lampen, A.; Joos, T.O.; Poetz, O. Mass Spectrometry-Based Immunoassay for the Quantification of Banned Ruminant Processed Animal Proteins in Vegetal Feeds. Anal. Chem. 2018, 90, 4135-4143. [CrossRef]

22. Lecrenier, M.C.; Marbaix, H.; Dieu, M.; Veys, P.; Saegerman, C.; Raes, M.; Baeten, V. Identification of specific bovine blood biomarkers with a non-targeted approach using HPLC ESI tandem mass spectrometry. Food. Chem. 2016, 213, 417-424. [CrossRef]

23. Sentandreu, M.A.; Fraser, P.D.; Halket, J.; Patel, R.; Bramley, P.M. A Proteomic-Based Approach for Detection of Chicken in Meat Mixes. J. Proteome Res. 2010, 9, 3374-3383. [CrossRef]

24. Ortea, I.; O'Connor, G.; Maquet, A. Review on proteomics for food authentication. J. Proteom. 2016, 147, 212-225. [CrossRef] [PubMed]

25. Palmblad, M.; Deelder, A.M. Molecular phylogenetics by direct comparison of tandem mass spectra. Rapid Commun. Mass Spectrom. 2012, 26, 728-732. [CrossRef] [PubMed]

26. Espe, M.; Andersen, S.M.; Holen, E.; Rønnestad, V.; Veiseth-Kent, E.; Zerrahn, J.E.; Aksnes, A. Methionine deficiency does not increase polyamine turnover through depletion of hepatic S-denosylmethionine. Br. J. Nutr. 2014, 112, 1274-1285. [CrossRef] [PubMed]

27. Liland, N.S.; Biancarosa, I.; Araujo, P.; Biemans, D.; Bruckner, C.G.; Waagbø, R.; Torstensen, B.E.; Lock, E.-J. Modulation of nutrient composition of black soldier fly (Hermetia illucens) larvae by feeding seaweed-enriched media. PLOS ONE 2017, 12, 0183188. [CrossRef]

28. Dumas, J.P.; Lettre de, M. Dumas a, M. Gay-Lussac, sur le procedes de l'analyse organique. Ann. Chim. Phys. 1831, 2, 198-215.

29. Biancarosa, I.; Espe, M.; Bruckner, C.G.; Heesch, S.; Liland, N.; Waagbø, R.; Torstensen, B.; Lock, E.J. Amino acid composition, protein content, and nitrogen-to-protein conversion factors of 21 seaweed species from Norwegian waters. J. Appl. Phycol. 2016, 29, 1001-1009. [CrossRef]

30. Wiśniewski, J.R.; Zougman, A.; Nagaraj, N.; Mann, M. Universal sample preparation method for proteome analysis. Nat. Methods 2009, 6, 359. [CrossRef]

31. Distler, U.; Kuharev, J.; Navarro, P.; Tenzer, S. Label-free quantification in ion mobility-enhanced data-independent acquisition proteomics. Nat. Protocols 2016, 11, 795. [CrossRef]

32. An R Package for Proteomics Data Quality Control. R package version 1.18.1. Available online: https: //githubcom/wenbostar/proteoQC (accessed on 2 May 2019).

33. R: A Language and Environment for Statistical Computing. Available online: https:/wwwR-projectorg/ (accessed on 2 May 2019). 
34. RStudio: Integrated Development for R. Available online: http://wwwrstudiocom/ (accessed on 2 May 2019).

35. Craig, R.; Beavis, R.C. TANDEM: Matching proteins with tandem mass spectra. Bioinformatics 2004, 20, 1466-1467. [CrossRef] [PubMed]

36. Nesvizhskii, A.I.; Keller, A.; Kolker, E.; Aebersold, R. A statistical model for identifying proteins by tandem mass spectrometry. Anal. Chem. 2003, 75, 4646-4658. [CrossRef]

37. Rieder, V.; Blank-Landeshammer, B.; Stuhr, M.; Schell, T.; Biß, K.; Kollipara, L.; Meyer, A.; Pfenninger, M.; Westphal, H.; Sickmann, A.; et al. DISMS2: A flexible algorithm for direct proteome- wide distance calculation of LC-MS/MS runs. BMC Bioinformatics 2017, 18, 148. [CrossRef]

38. Venny. An Interactive Tool for Comparing Lists with Venn's Diagrams. Available online: http://bioinfogp. cnb.csic.es/tools/venny/index.html (accessed on 2 May 2019).

39. Janssen, R.H.; Vincken, J.-P.; Van den Broek, L.A.M.; Fogliano, V.; Lakemond, C.M.M. Nitrogen-to-Protein Conversion Factors for Three Edible Insects: Tenebrio molitor, Alphitobius diaperinus, and Hermetia illucens. J. Agric. Food. Chem. 2017, 65, 2275-2278. [CrossRef] [PubMed]

40. Schiavone, A.; De Marco, M.; Martínez, S.; Dabbou, S.; Renna, M.; Madrid, J.; Hernandez, F.; Rotolo, L.; Costa, P.; Gai, F.; et al. Nutritional value of a partially defatted and a highly defatted black soldier fly larvae (Hermetia illucens L.) meal for broiler chickens: apparent nutrient digestibility, apparent metabolizable energy and apparent ileal amino acid digestibility. J. Anim. Sci. 2017, 8, 51. [CrossRef] [PubMed]

41. Espe, M.; Rathore, R.M.; Du, Z.-Y.; Liaset, B.; El-Mowafi, A. Methionine limitation results in increased hepatic FAS activity, higher liver 18:1 to 18:0 fatty acid ratio and hepatic TAG accumulation in Atlantic salmon, Salmo salar. Amino Acids 2010, 39, 449-460. [CrossRef]

42. Belghit, I.; Skiba-Cassy, S.; Geurden, I.; Dias, K.; Surget, A.; Kaushik, S.; Panserat, S.; Seiliez, I. Dietary methionine availability affects the main factors involved in muscle protein turnover in rainbow trout (Oncorhynchus mykiss). Br. J. Nut. 2014, 112, 493-503. [CrossRef]

43. Finke, M.D. Complete nutrient composition of commercially raised invertebrates used as food for insectivores. Zoo Biol. 2002, 21, 269-285. [CrossRef]

44. Finke, M.D. Complete nutrient content of four species of commercially available feeder insects fed enhanced diets during growth. Zoo Biol. 2015, 34, 554-564. [CrossRef]

45. Salze, G.P.; Davis, D.A. Taurine: A critical nutrient for future fish feeds. Aquaculture 2015, 437, $215-229$. [CrossRef]

46. National Research Council. Nutrient Requirements of Fish and Shrimp; The National Academies Press: Washington, DC, USA, 2011; p. 363.

47. Njaa, L.; Utne, F. A comparison of the amino acid composition of fifteen species of whole fish. Fisk. Dir. Skr. Ernaering 1982, 2, 25-33.

48. Bußler, S.; Rumpold, B.A.; Jander, E.; Rawel, H.M.; Schlüter, O.K. Recovery and techno-functionality of flours and proteins from two edible insect species: Meal worm (Tenebrio molitor) and black soldier fly (Hermetia illucens) larvae. Heliyon 2016, 2, 00218. [CrossRef]

49. Ericsson, C.; Peredo, I.; Nister, M. Optimized protein extraction from cryopreserved brain tissue samples. Acta Oncol. 2007, 46, 10-20. [CrossRef]

50. Cilia, M.; Fish, T.; Yang, X.; McLaughlin, M.; Thannhauser, T.W.; Gray, S. A comparison of protein extraction methods suitable for gel-based proteomic studies of aphid proteins. J. Biomol. Tech. 2009, 20, 201-215.

51. Gatto, L.; Breckels, L.M.; Naake, T.; Gibb, S. Visualization of proteomics data using R and bioconductor. Proteomics 2015, 15, 1375-1389. [CrossRef]

52. MassIVE Dataset: MSV000083737. Available online: https://massive.ucsd.edu/ProteoSAFe/dataset.jsp? accession=MSV000083737 (accessed on 6 May 2019). [CrossRef]

53. Yin, C.; Shen, G.; Guo, D.; Wang, S.; Ma, X.; Xiao, H.; Liu, J.; Zhang, Z.; Liu, Y.; Zhang, Y.; et al. InsectBase: A resource for insect genomes and transcriptomes. Nucleic Acids Res. 2016, 44, D801-D807. [CrossRef] [PubMed]

54. Wulff, T.; Nielsen, M.E.; Deelder, A.M.; Jessen, F.; Palmblad, M. Authentication of Fish Products by Large-Scale Comparison of Tandem Mass Spectra. J. Proteome Res. 2013, 12, 5253-5259. [CrossRef] 
55. D'Alessandro, A.; Zolla, L. We Are What We Eat: Food Safety and Proteomics. J. Proteome Res. 2012, 11, 26-36. [CrossRef]

56. Nessen, M.A.; van der Zwaan, D.J.; Grevers, S.; Dalebout, H.; Staats, M.; Kok, E.; Palmblad, M. Authentication of Closely Related Fish and Derived Fish Products Using Tandem Mass Spectrometry and Spectral Library Matching. J. Agric. Food Chem. 2016, 64, 3669-3677. [CrossRef]

(c) (2)

(C) 2019 by the authors. Licensee MDPI, Basel, Switzerland. This article is an open access article distributed under the terms and conditions of the Creative Commons Attribution (CC BY) license (http://creativecommons.org/licenses/by/4.0/). 